been crushed, evidently by the pressure of the throat.

An extensive report on the Ruffed Grouse (Bump, Darrow, Edminster, and Crissey. 1947. The Ruffed Grouse, life history, propagation, management. New York State Conservation Dept., New York, 915 pp.) shows that this species eats a great variety of invertebrate animals, including snails (87 in one crop), and small clams and mussels. As expected, they seldom prey on vertebrates. They have, however, eaten reptiles, birds, and mammals. Records include a 17-inch green snake and a slightly smaller garter snake. Bones from a small unidenti- fied bird were found in one grouse and feather remains in another. The only reported mammalian food item, however, was based on the "even more mystifying" appearance of rabbit hairs in two other specimens. The above reference relates such peculiar prey species to "stress of circumstances." The present record is further evidence that Ruffed Grouse may occasionally attempt to take a small mammal, though this may not generally be feasible.

I am indebted to Dr. Jennifer $M$. Walker for the plant identifications. W. Harvey Beck identified the snail and the mouse.

\title{
SLATE-COLORED JUNCO NESTING IN BARN SWALLOW NEST; BROWN-HEADED COWBIRD PARASITISM ON JUNCO AND BARN SWALLOW
}

by David R. M. Hatch, Oak Lake, Manitoba

On June 19, 1968, I observed a pair of Slate-colored Juncos carrying food into an old Barn Swallow nest under the eave of the museum building in the town of Wasagaming in Riding Mountain National Park. Upon examination, the nest was found to contain a nestling Brown-headed Cowbird about six days old, but no young juncos. The nest, which was 13 feet above the ground, was lined with fine grasses and with an inner cup of horsehair. The old inner cup of the Barn Swallow nest was full of grass which could even be seen above the mud edge. Both adult juncos continued to feed the cowbird until June 22, at which time the young cowbird left the nest. I saw a junco on June 26 feeding a cowbird that could fly, and as they were only a little over 100 yards from the nest site assumed that they were the same birds. I have been unable to find a record of a junco nesting in similar circumstances.

Two of three active Barn Swallow nests found on June 19 under the eaves of the same building contained cowbird eggs. One nest held two cowbird eggs and one swallow egg; the other nest contained one cowbird egg and three swallow eggs. On June 24 all of the nests were knocked down by maintenance crews in preparation for sanding and varnishing the wooden building. Although we therefore lack information on the outcome of these particular clutches, it is clear that both pairs of swallows had accepted the foreign eggs and were incubating them during the period of observation. When one considers that there was a wide variation in the period in which the eggs were laid, two or more female cowbirds must have been involved. For example, both sets of eggs were still unhatched June 24, whereas the cowbird that hatched in the junco nest left the nest on its own accord by June 22 and was flying by June 26.

The Barn Swallow is listed by H. C. Friedmann (Host relations of parasitic cowbirds, 1963, U.S. Nat'l Mus. Bull. 233) as a "a very infrequent victim" and only five specific records 
are given. The Slate-colored Junco is "an infrequently reported host; probably it is molested only very slightly by the Brown-headed Cowbird. Eighteen instances have come to my attention." Friedmann goes on to state, however: "In the Peace River District of British Columbia,
Cowan found that no fewer than four out of five junco nests which were observed were parasitized, evidence which suggests that in this region the bird is a commoner host than it has been found to be elsewhere." Perhaps the same is true for the Riding Mountain area.

\section{MOCKINGBIRD SEEN AT MARSHALL}

by Gordon Friedrick, Marshall, Saskatchewan

On July 13 and 14, 1968 we identified a Mockingbird in our yard. I was able to get within 20 feet of the bird on the late afternoon of July 14, and I watched the Mockingbird for about two hours using field glasses most of the time.

The first day we saw the Mockingbird it was quite wary, but it kept coming back to some Manitoba maple and saskatoon bushes around our second house. The Catbirds that nest here every year seemed to keep close to the Mockingbird. I was able to observe the bird feeding and flying at quite close range.

I might add that I found a Blackbilled Cuckoo in the spring of 1947, which was identified by A. L. Rand,

\section{ANNOUNCING BENT'S FRINGILLIDS}

The last unit of the famous Bent life histories series is now available. Compiled and edited by Oliver $\mathrm{L}$. Austin, Jr., this three volume work contains exhaustive species studies made by both professional and amateur ornithologists, including John Lane of Brandon who compiled the material on the Baird's Sparrow. Order Life histories of North American cardinals, grosbeaks, buntings, towhees, finches, sparrows, and allies (1968. Smithsonian Institution, Washington, D.C., Bulletin 237), in three parts for $\$ 9.25$ (Canadian) from Blue Jay Bookshop, Frank Brazier, Manager, Box 1121, Regina.
Acting Chief of the Biological Division, Ottawa, and according to him, this record was one of the most northern records for Saskatchewan.

Editor's Note: Mockingbird records gathered together by Frank Brazier for an article in the Blue Jay, 22:63-74 extend the range for this species in Saskatchewan as far north as Prince Albert. The town of Marshall has the same latitude as Prince Albert, but it lies approximately 170 miles to the west, near the Alberta border, in an area where no previous records were reported by Brazier. The continent's farthest north record, according to Brazier (Blue Jay, 22:151) was a bird seen May 31, 1955 at Churchill, Manitoba.

\section{CHRISTMAS BIRD COUNT 1968}

In your report, list the numbers of each species seen on the ONE BEST DAY between Friday, December 20, 1968 and Wednesday, January 1, 1969 (inclusive). In addition, list other species (number of individuals and date seen) between December 20 and January 1. Send reports as soon as possible to

$$
\begin{gathered}
\text { MRS. MARY HOUSTON, } \\
863 \text { University Drive, } \\
\text { Saskatoon. }
\end{gathered}
$$

